\title{
Recent History, Use and Forgetfulness of the Cypress Forest of Fontegreca (Southern Italy)
}

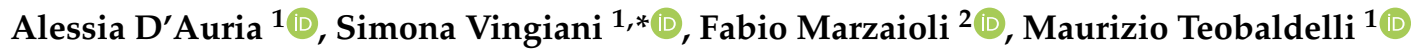 \\ and Gaetano Di Pasquale ${ }^{1}$ (D) \\ 1 Department of Agricultural Sciences, University of Naples Federico II, Via Università 100, 80055 Portici, Italy; \\ alessia.dauria@unina.it (A.D.); maurizio.teobaldelli@gmail.com (M.T.); gaetano.dipasquale@unina.it (G.D.P.) \\ 2 CIRCE INNOVA, Department of Mathematics and Physics, Università degli Studi della Campania \\ Luigi Vanvitelli, Viale Lincoln 5, 81100 Caserta, Italy; fabio.marzaioli@unicampania.it \\ * Correspondence: simona.vingiani@unina.it; Tel.: +39-0812539180
}

Received: 13 October 2020; Accepted: 27 November 2020; Published: 2 December 2020

\begin{abstract}
The cypress (Cupressus sempervirens) is characterized by a very ancient history linked to the wide employment for the technological properties of its wood and for its symbolic value. Although this tree was often considered as a species introduced in Italy, the first genetic studies showed, instead, the presence of an autochthonous population of $C$. sempervirens in the forest of Fontegreca (Matese massif, Southern Italy), which constitutes the unique autochthonous cypress woodland present in Southwestern and Western Europe. Therefore, investigations were carried out in selected (using geomorphological criteria) areas of the forest, through soil chemical analysis, identification and ${ }^{14} \mathrm{C}$ dating of soil charcoals. Indeed, we hypothesize that these analyses allow clarifying the history of this woodland characterized by the dominance of the cypress in the forest cover. Areas at medium-low $\left(17-29^{\circ}\right)$ slope gradient on the eastern and southern slopes of the forest were investigated and sampled, following pedological criteria (soil horizons order). Soil morphological and chemical analysis showed humus-rich surface horizons, thin $(15-30 \mathrm{~cm})$ and poorly developed (young) soils, overlapping the bedrock limestones. The first soil charcoal analysis data highlighted the presence of a previous landscape characterized by several species (e.g., Pistacia, Ostrya carpinifolia, Juniperus sp. and Pinus sp.) and, probably, by a different forest structure. Ongoing charcoal identification and ${ }^{14} \mathrm{C}$ dating will likely give a better understanding of both (1) the cypress history and (2) the development of this forest landscape.
\end{abstract}

Keywords: soil charcoal analysis; wood anatomy; soil chemical properties; ${ }^{14} \mathrm{C}$ dating; Cupressus sempervirens; Zappini forest; forest history; timber production

\section{Introduction}

During the Late Holocene, the distribution of several forest tree species was strongly modified by humans [1]. From late Neolithic [2], in the Mediterranean area, the development of permanent land-use practices, such as woodland management, crop cultivation and livestock farming, brought to a rapid decline of forest area [3], also due to plant domestication [4].

Cupressus s.l. is distributed throughout the Northern hemisphere, in the Mediterranean region, in Eurasia and North and Central America [5]. Mediterranean Cupressus taxa have today a very fragmented distribution [6] as a result of both population dynamics, occurred during their long history, and human pressure [6,7]. The Mediterranean Cupressus taxa were described as separate species but their taxonomy was reviewed many times [8]. Around the Mediterranean sea, the Cupressus s.s. (Old World Cupressus) [9] is generally represented by four taxa [10-13]: (1) C. atlantica Gaussen or Moroccan cypress, distributed in the Moroccan Central High Atlas, [8], (2) C. numidica or Tunisian cypress-considered 
by most taxonomists a variety of $C$. sempervirens (C. sempervirens var. numidica Trab.) - currently represented by two populations on the Tunisian ridge, the Saharan cypress, (3) C. dupreziana Camus, limited to one endemic population in the Tassili Massif in Southeast Algeria [7] and (4) Cupressus sempervirens L., or Italian cypress, a species with the largest distribution in the Mediterranean area, although, currently, playing a residual role in the forest vegetation [7].

C. sempervirens $\mathrm{L}$. is constituted by two different varieties: $C$. sempervirens var. horizontalis characterized by a broad crown and the $C$. sempervirens var. pyramidalis with a conical form [14]; this latter is the most widely planted [15]. This cypress occurs in Mediterranean climates, with dry and hot summers and rainy winters, and in semiarid climates in the eastern and interior areas of its range [12]. It is a pioneer species, growing better than other species on rocky and dry soils [16,17]. Currently, natural stands occur in areas reaching east towards the Caucasus and Southwestern Iran, from sea level up to $2000 \mathrm{~m}$ (Crete) [6] to the Aegean islands and Cyrenaica in Libya [7].

During the Pleistocene, this tree was widely distributed throughout the entire Mediterranean basin, from Israel [18], to Malta [19], Italy [20-22] and Spain [23]; during the same period, the genus Cupressus suffered a strong reduction of its areal, which led, in Southern Europe, to its extinction [24]. Nevertheless, the recent work of Bagnoli et al. [25] — with the finding of remnants, depauperated populations in the central Mediterranean area-opens up new questions, and the survival in Southern Europe of Cupressus during the last glaciations is still subject of research and discussion [26].

In the recent Holocene, the Italian cypress was cultivated in many countries around the Mediterranean Sea [27]. In the Italian peninsula, the high abundance and heterogeneity of the botanical remains of C. sempervirens (wood, charcoals and cones) found during the archaeological excavations conducted in the Vesuvian area confirmed the presence of a varied use of this species and of its precious and highly appreciated timber during the Roman period [28].

In particular, the finding of a plantation of cypress in the ancient Campania suggests the intention of local populations of producing structural timber of the highest quality $[28,29]$. Interestingly, the ancient Romans gave a high economic value to cypress plantations and considered the cypress wood of thirteen years old as "dowry of the daughter" [30]. Indeed, the cypress is a tree with a characteristic shape, which provides wood of excellent quality. The widespread use of this species during the Roman period provides us with indications on the in-depth knowledge, by the local population, of the technological properties of cypress wood, such as its resistance to fungi and insects [31]. Archaeobotanical data suggest that these characteristics were also well-known in pre-Roman populations of a large area of the Italian peninsula; indeed, during the sixth and fifth centuries $B C$, the cypress was used as a coating for the wells [32,33], and, before then, the presence of cones and seeds in Bronze Age sites of Central Italy [34] suggests that the Italian cypress was, also, previously used in the Italian peninsula [28].

Although many of the studies reported above seem to confirm the presence of an autochthonous cypress in the Italian forests—-today, represented by the relic forest of Fontegreca [26] —however, a clear consensus is still not reached due to palaeoclimatological reasons [26].

Surprisingly, the cypress forest of Fontegreca was never cited in both silvicultural and botanical books [35-37]. Its origin is unknown, and its history is based on several legends rather than historical documents. For this reason, this research aimed to carry out an in-depth investigation of the recent history of the cypress forest of Fontegreca by reviewing historical documents, together with soil charcoal and pedological analysis.

\section{Materials and Methods}

\subsection{Study Area}

The municipal area of Fontegreca is located in the Campania Region (Southern Italy) (Figure 1) in the upper Volturno valley on the extreme slopes of Matese Massif. Behind the village of Fontegreca, there is the thick wood (70 ha) of the Fontegreca cypress forest. It covers two slopes, one slope forming the main, almost pure, nucleus called Monte dei Cipressi, the other slope having lower density but 
increasing during the last years [38]. The altitude of the Fontegreca forest ranges from 226, along the Sava River (locality of Starze-Traversa), to $1085 \mathrm{~m}$ asl at Mt Caselle Iannitti.

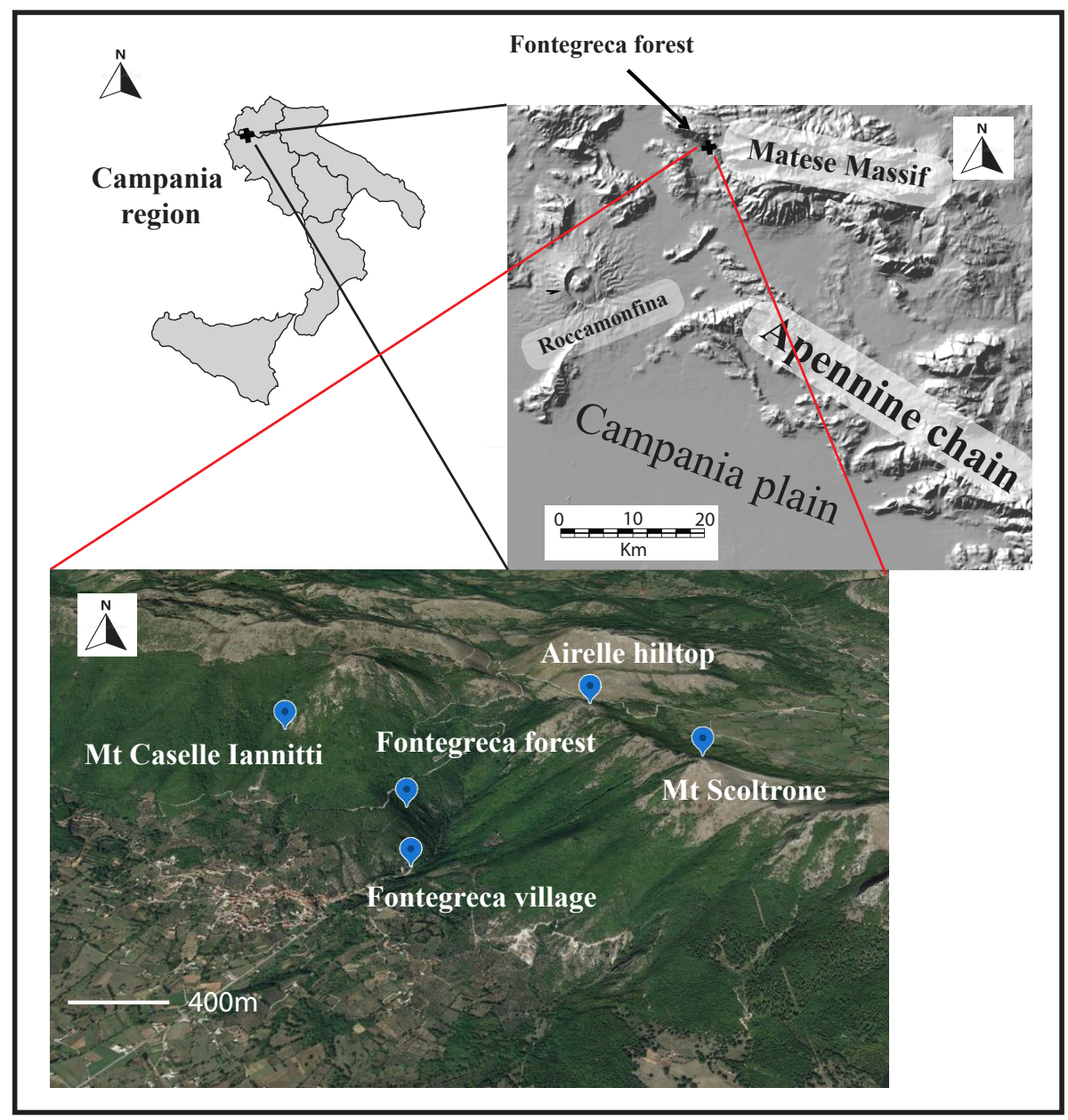

Figure 1. Location of the study area, the Fontegreca forest.

The rock substrate of the Matese Massif mainly consists of carbonate rocks belonging to the Meso-Cenozoic carbonate platform domain [39], while siliciclastic deposits date back to Miocene outcrops on the boundary of the mountain in tectonic depressions. Due to the high degree of fracturing, these limestones are characterized by a poorly developed surface drainage network and prevailing subterranean karst drainage. Therefore, the lithological composition of the study area is mainly pre-Quaternary bedrock. Regarding the soil cover, Apennine reliefs of the Campania Region are generally characterized by soils developing directly from limestones or from pyroclastic materials (ash and pumice falls from Phlegrean Fields or Vesuvius), slope and fan deposits overlying the limestones [40]. In the case of parent material of volcanic origin, there is frequently a genesis of Andosols or soils with andic properties. These soils are known by the literature for their excellent properties [41], providing high chemical and physical fertility to ecosystems [42], both in volcanic districts $[43,44]$ and in nonvolcanic mountain landscapes $[45,46]$ but, also, an inside "fragility" to land degradation $[47,48]$ and pollution $[49,50]$.

Climate data refer to the period 2010-2019 collected by the nearby-about $4 \mathrm{~km}$ away from the area of study -meteorological station located in Letino (Lat. $41.45391667^{\circ} \mathrm{N}$, Long. $14.25302778^{\circ} \mathrm{E}$, $1050 \mathrm{~m}$ asl) [51]. Meteorological data showed a typical Mediterranean climate with (1) the average annual temperature of $11^{\circ} \mathrm{C}$ with the presence of higher monthly average temperatures during the summer period (June, July and August, with the latest being the hottest month with an average 
temperature of $\left.21^{\circ} \mathrm{C}\right)$; (2) temperature drops in January and February $\left(3^{\circ} \mathrm{C}\right.$ is the average monthly temperature); (3) rainy season in the autumn, with the highest monthly average rainfall in November (260 $\mathrm{mm}$ ) and the lowest in August (44 mm). During the selected period (10 years), the total annual rainfall ranged from 1190 (year 2011) to $2048 \mathrm{~mm}$ (year 2013). The vegetative period (May-September) showed a clear decrease of rainfall.

The importance of the cypress forest of Fontegreca lies in the fact that it is the only example of natural cypress forest in Western Europe characterized by C. sempervirens var. horizontalis [25]. The local name of these cypresses is Zappini; the plant name "zappino" comes from latin sa(p)pinus (n.b. Romans used this word for several conifer species) [52]. As showed by the diameter distribution of the trees, the natural regeneration of the cypress in the Fontegreca forest was constant and abundant over the years and depended by environmental factors and particular pedological conditions. Indeed, it was more abundant in the stony slopes, on dry stone walls, along the paths and in the open places. A negative effect of cypress renewal was, usually, the shading of the hardwoods and the presence of herbaceous species. In the study area, the cypress vegetated both on shallow and rocky landscape and on alluvial soils along the Sava river. Two different types of forests were identified at Fontegreca. A pure cypress forest, characterized by high trees density, while the mixed forest was, instead, characterized by the presence of broadleaf deciduous species such as Ostrya carpinifolia Scop., Carpinus betulus L., Fraxinus ornus L., Quercus pubescens L., Quercus ilex L. and Quercus cerris L. Along the Sava River, cypress was associated with Salix spp., Populus alba L., Ficus carica L., Morus alba L., Ulmus minor Mill., Acer campestre L., Acer monspessulanum L., Acer opalus var. obtusatum Mill. and Alnus cordata (Loisel.) Duby. Finally, the most common shrubs in this forest were Juniperus oxycedrus L., Coronilla emerus L., Cistus incanus L., Helichrysum italicum (Roth) G. Don and Spartium junceum L. [53].

A wide bibliographic research was carried out in the historical archives of the city of Fontegreca municipality and in the state archives of Caserta.

\subsection{Analytical Methods}

A geomorphological analysis of the Fontegreca area was carried out to acquire knowledge on the environmental factors affecting the forest, due to its importance in the deposition processes of charcoals and sediments. A digital elevation model (DEM) processed by vector data with 1-m resolution was used to obtain a slope map in Arc-GIS 10.

Two areas were selected for the soil sampling: the first (L1) located on the East-facing slope (Lat. $41.461313^{\circ} \mathrm{N}$, Long. $14.192934^{\circ} \mathrm{E}$ ) at $400 \mathrm{~m}$ asl and the second (L2) on the South-facing slope (Lat. $41.459939^{\circ} \mathrm{N}$, Long. $14.186706^{\circ} \mathrm{E}$ ) at $430 \mathrm{~m}$ asl (Figure 2). Both L1 and L2 were selected in areas of medium-low $\left(17-29^{\circ}\right)$ slope gradients in order to have more favorable local conditions for the deposition and conservation of charcoals. In order to select the most representative sites for the soil profile excavation, several (6 or 7 for each area) preliminary observations were carried out in both L1 and L2 areas by digging a minipit in the soil. In L1, one soil profile (FONT1) was dug and analyzed and one soil profile (FONT2) in L2. Soil profiles were described and collected following the FAO (Food and Agriculture Organization of the United Nations) guidelines [54]. Bulk soil samples for chemical analyses were air-dried and sieved at $2 \mathrm{~mm}$. The percentage of coarse fragments $(>2 \mathrm{~mm})$ was calculated on a weight basis. Chemical analyses were carried out on the fine earth fraction $(<2 \mathrm{~mm})$ : soil $\mathrm{pH}$ was determined potentiometrically from soil- $\mathrm{H}_{2} \mathrm{O}$ and soil- $\mathrm{KCl} 1-\mathrm{M}$ solution (1:2,5 ratio) suspensions; organic matter (OM) content was determined following Walkley and Black's [55] procedure; the cation exchange capacity (CEC) was determined according to Mehlich [56], with barium chloride triethanolamine buffered at $\mathrm{pH} 8.2$, and exchangeable cations $\left(\mathrm{Ca}^{2+}, \mathrm{Mg}^{2+}, \mathrm{Na}^{+}\right.$ and $\mathrm{K}^{+}$) were measured by ICP-OES (Inductively Coupled Plasma-Optical Emission Spectroscopy, Thermo Scientific ICAP 4200, Waltham, MA, USA). 


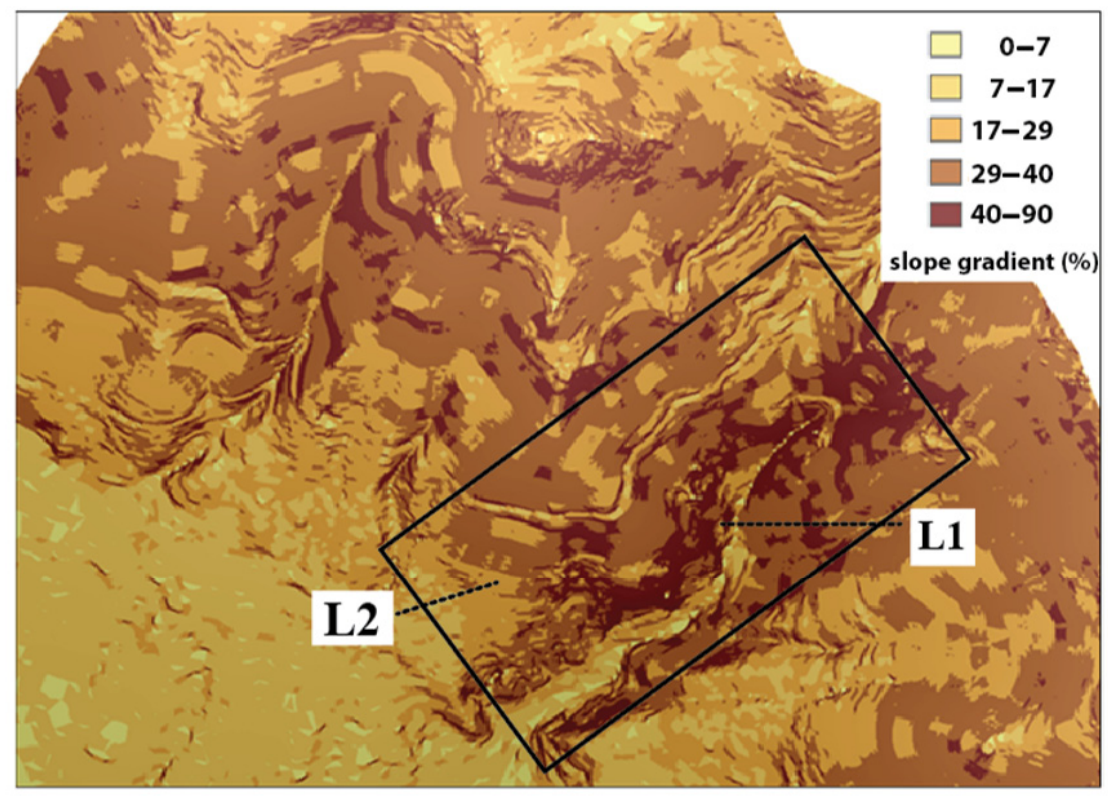

Figure 2. Map of the slope gradient. The Fontegreca forest is enclosed in the black rectangle. L1 and L2 are the sampling areas.

Soil charcoal samples were collected in both soil profiles (FONT1 and FONT2), following the genetic horizons, for a total of 6 samples. Sample collection and laboratory treatments followed the standard procedure of the soil charcoal analysis methodology $[57,58]$. The volume of the collected soil samples did not exceed $2 \mathrm{~kg}$. The different samples were air-dried and wet-sieved through sieves with 4-mm, 2-mm and 0.5-mm mesh sizes. Charcoals identification was performed for assemblages of charcoal pieces greater than $0.5 \mathrm{~mm}$. Smaller charcoal pieces were excluded, because they were not taxonomically identifiable. Taxonomical identification was carried out using an incident light microscope at magnifications of $10 \times, 20 \times, 50 \times$ and $100 \times$ and consulting both wood anatomy atlases [59-62] and the reference collection of the Plant and Wood Anatomy Laboratory of the Department of Agricultural Sciences at the University of Naples Federico II.

Charcoal samples of $C$. sempervirens collected from FONT1 and FONT2 underwent the classical ABA (acid-base-acid) pretreatment procedure assisted by Teflon bags to (i) remove exogenous C sources, potentially affecting the accuracy of dating (i.e., carbonates and organic matter) and (ii) allow the maximum yield of recovery of the sample [63]. Overnight, dried samples underwent a sealed tube combustion, and the produced $\mathrm{CO}_{2}$ was graphitized by Sealed Tube Zinc reduction [64]. Produced graphite, together with iron powder, was pressed into 1-mm Al cathodes and measured by means of a NEC (National Electrostatic Corporation, Madison, WI, USA) AMS (Accelerator Mass Spectrometry) at the CIRCE centre Università della Campania Mathematics and Physics Department [65] into an analytical batch comprising blank samples, normalization and check standards [66]. Measured ${ }^{14} \mathrm{C}$ abundances were expressed as $\mathrm{F}^{14} \mathrm{C}$ [67] and calibrated by oxcal [68] with [69] dataset.

\section{Results}

\subsection{Historical Documentation}

The analysis of historical sources, carried out using both documents kept by the State Archive and others available from the regional and national authorities confirmed the presence of the forest since the early 16th century and gave us useful information regarding the management that has been carried out since now and main dendrometric characteristics of the forest during the centuries (Table 1). 
Table 1. Historical sources from the State Archive and others available documents from the regional and national authorities.

\begin{tabular}{|c|c|c|c|}
\hline Historical Document & Year & Description & References \\
\hline Civic Uses if Fontegreca-ASC & 1506 & "Bosco degli Zappini (Caserta), un caso di cipresseta subnaturale" & [38] \\
\hline Memoria historica del Sannio & 1644 & $\begin{array}{l}\text { "nella Terra di Fossaceca è una bella selva solo di alti, e folti cipressi si ... alberi si grossi e grandi da' quali non } \\
\text { poca utilità, e commodità si cava, poiché vi si tagliano legni fuori di modo lunghi, larghi ed odoriferi" }\end{array}$ & {$[70]$} \\
\hline Sacred Royal Council & 1756 & $\begin{array}{l}\text { “[ ... ] distante un terzo di miglio dalla terra sudetta vi stà posta altra cappella, sotto il titolo di Sa. Maria } \\
\text { delli Cipressi }[\ldots \text { ] }\end{array}$ & [71] \\
\hline $\begin{array}{l}\text { Dissertazioni istoriche delle } \\
\text { antichità alifane }\end{array}$ & 1776 & $\begin{array}{l}\text { "Più a basso alquante miglia a sinistra vi cade un altro fiumicello sotto Capriati a fronte del Bosco dei Cipressi } \\
\text { detta la Sava che dalle falde del Matese ha la sua scaturigine dentro un Valle a fianchi di una Selva di alti cipressi, } \\
\text { detti da quei del paese Zappini, da sopra il castello di Fossaceca, che si crede la Fossa greca degli antichi" }\end{array}$ & [72] \\
\hline Lavori Demaniali & 1930-1938 & $\begin{array}{l}\text { “Sin dal } 1800 \text { fra il Feudatario Duca di Laurenzana e l’Università di Fossaceca furono fissate in delle } \\
\text { capitolazione e diritti reciproci. Da esse appare che l'Università gode ed esercita il diritto di legnare e pascere su } \\
\text { alcuni comprensori come quelli detti. }[\ldots] \text {, Selva dei Cipressi, }[\ldots]\end{array}$ & [73] \\
\hline Rivista Forestale Italiana & 1940 & $\begin{array}{l}\text { “[ ... ] particolarmente rivestito da una formazione di carpino bianco cui verso la quota } 600 \text { si frammischia il } \\
\text { cipresso; l'importanza di questa seconda specie aumenta rapidamente man mano che si scende, fino a dar luogo } \\
\text { a una cipresseta pressoché pura }[\ldots] \text { " . }\end{array}$ & [74] \\
\hline
\end{tabular}


Indeed, the presence of Fontegreca cypress forest was mentioned in an important document [38] that indicated the existence of a relief of the 1506 (Civic Uses of Fontegreca) and specified how the "cipresseta" was not considered as a protective forest (e.g., against hydrogeological risk), but, instead, it was subject to timber harvesting and grazing. The second testimony of the presence of Fontegreca cypress forest dates back to 1644 by Ciarlanti, archpriest of the Isernia Cathedral. In his document, he reported the presence of a mature high forest characterized by tall and thick cypress trees producing long and very perfumed planks of wooden monoxyle [70].

In 1756, in the Sacred Royal Council, a document of the Aragonese Institution, some of the feudal lands were described in detail, including Fontegreca; it was the only court responsible for the disputes between feudal and feudatory, both civil and penal. In this document, it was cited especially as the Church of St. Mary of the Cypresses and the nearby cypress forest [71].

In 1776, the archpriest Trutta described the landscape surrounding the forest; he mentioned the presence of a river, called La Sava, under Capriati in front of the cypress forest that started from the slopes of the Matese mountains and arrived inside a valley characterized by the presence of a high forest cypress stand called Zappini by the inhabitants of the country [72].

Concerning the use of the forest, burdened by civic uses, important information comes from the report of Buontempo (1930-1938); this document indicated that the land of the Municipality of Fontegreca was utilized for grazing and wood collection since the Middle Ages [73].

Besides, to understand the changes in cypress forest expansion that occurred over the last century, photographic documents were compared; in particular, Banti [74] published a picture of the forest dated 1940 and indicated the total area of the cypress forest. Another important picture useful to estimate the surface of the cypress forest of Fontegreca is stored in the Filangieri Archive and dates back to 1976 (today, stored in the Centro Museale delle Scienze Agrarie, University of Naples Federico II). The comparison between the pictures (1940) with this photo realized in the 2019 permits to evaluate the changes of the extension of this forest during this period.

\subsection{Landscape and Soil Data}

The rock substrate outcropping on the slopes was made by very fractured limestones furrowed by poor surface drainage network, due to prevailing subterranean karst drainage. Cypress roots were frequently found penetrating the rock, very likely to be strongly anchored to the substrate. Moreover, not far from the village of Fontegreca (approximately $15 \mathrm{~km}$ towards east), the evidence of glacial processes, such as glacial cirques affecting the Matese Mts. during the Quaternary, were found on the Bortheastern slope of Mt. Miletto, between 2000 and $1775 \mathrm{~m}$ asl [75].

Soil analyses were reported in Tables 2 and 3. The soil depth in L1 ranged around 25 (FONT1) and $30 \mathrm{~cm}$ (Figure $3 \mathrm{~A})$, while in L2, thinner soils $(15-20 \mathrm{~cm}$, until the white limestone begins to be present) were identified (Figure 3B).

In L1, FONT1 was characterized by a moderately altered organic top layer (Oe) 5-cm thick, having black (5YR 2.5/1) color and high organic matter (OM) content (40\%), as well as high $(67 \mathrm{cmol}(+) / \mathrm{kg})$ cation exchange capacity (CEC) due to the presence of abundant organic colloids, which were mainly saturated by $\mathrm{Ca}(52 \mathrm{cmol}(+) / \mathrm{kg})$, then by $\mathrm{Mg}(13 \mathrm{cmol}(+) / \mathrm{kg}), \mathrm{K}(1 \mathrm{cmol}(+) / \mathrm{kg})$ and $\mathrm{Na}(0.1 \mathrm{cmol}(+) / \mathrm{kg})$ cations. Organ-mineral horizons A1 and A2, characterized by dark, reddish brown (5YR 2.5/2) and dark brown (7.5 YR 3/2) colors, respectively, were found below the Oe horizon. OM decreased with depth (A1 and A2 had 15\% and 12\%, respectively), as well as the CEC (58 and $46 \mathrm{cmol}(+) / \mathrm{kg}$ ), while the exchange complex was always saturated. The soil reaction was moderately alkaline ( $\mathrm{pH}$ 8.2-8.3). In L2, the A1 horizon of FONT 2 was dark brown-colored (10YR 2.5/2) and showed a similar content of OM compared with the same A1 horizon of FONT1. Nevertheless, A1 of FONT2 was characterized by a lower, slightly alkaline $\mathrm{pH}(7.8)$ coherently with a lower Ca content $(45 \mathrm{cmol}(+) / \mathrm{kg})$ of the exchangeable complex. 
Table 2. Data of the study site, anthracological analysis and chemical properties of FONT1 soil profile.

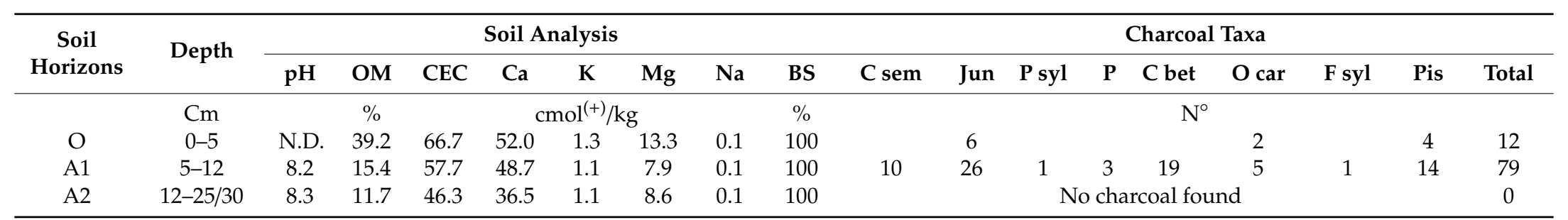

Coordinates: Lat. $41.461313^{\circ} \mathrm{N}$-Long. $14.192934^{\circ}$ E, Altitude: $400 \mathrm{~m}$ asl, Aspect: East, Slope: $20^{\circ}$. Vegetation: mixed forest with Cupressus sempervirens, Ostrya carpinifolia, Carpinus betulus, Quercus ilex. Legend: $\mathrm{pH}=$ soil reaction; $\mathrm{OM}=$ organic matter; $\mathrm{CEC}=$ cation exchange capacity; $\mathrm{Ca}, \mathrm{K}, \mathrm{Mg}, \mathrm{Na}=$ calcium, potassium, magnesium and sodium exchangeable cations; $\mathrm{BS}=$ base saturation. $\mathrm{C}$ sem = Cupressus sempervirens; Jun = Juniperus; $\mathrm{P}$ syl = Pinus type sylvestris; $\mathrm{P}=$ Pinus; $\mathrm{C}$ bet = Carpinus betulus; $\mathrm{O}$ car = Ostrya carpinifolia $; \mathrm{F}$ syl = Fagus sylvatica; Pis $=$ Pistacia

Table 3. Data of the study site, anthracological analysis and chemical properties of FONT2 soil profile.

\begin{tabular}{|c|c|c|c|c|c|c|c|c|c|c|c|}
\hline \multirow{2}{*}{ Soil Horizons } & \multirow{2}{*}{ Depth } & \multicolumn{8}{|c|}{ Soil Analysis } & \multirow{2}{*}{$\begin{array}{c}\text { Charcoal Taxa } \\
\text { C sem }\end{array}$} & \multirow{2}{*}{ Total } \\
\hline & & $\mathrm{pH}$ & OM & CEC & $\mathrm{Ca}$ & $\mathbf{K}$ & Mg & $\mathrm{Na}$ & BS & & \\
\hline & $\mathrm{cm}$ & & $\%$ & \multicolumn{4}{|c|}{$\mathrm{cmol}^{(+)} / \mathrm{kg}$} & & $\%$ & $\mathrm{~N}^{\circ}$ & \\
\hline $\begin{array}{c}\mathrm{O} \\
\mathrm{A} 1\end{array}$ & $\begin{array}{c}0-5 \\
5-10 / 15\end{array}$ & $\begin{array}{c}\text { N.D. } \\
7.8\end{array}$ & $\begin{array}{l}\text { N.D. } \\
18.17\end{array}$ & $\begin{array}{l}\text { N.D. } \\
45.1\end{array}$ & $\begin{array}{l}\text { N.D. } \\
33.0\end{array}$ & $\begin{array}{c}\text { N.D. } \\
0.8\end{array}$ & $\begin{array}{c}\text { N.D. } \\
11.1\end{array}$ & $\begin{array}{c}\text { N.D. } \\
0.1\end{array}$ & $\begin{array}{c}\text { N.D. } \\
100\end{array}$ & $\begin{array}{l}\text { No charcoal found } \\
2\end{array}$ & 2 \\
\hline
\end{tabular}

Coordinates: Lat. $41.459939^{\circ}$ N-Long. $14.186706^{\circ}$ E, Altitude: $430 \mathrm{~m}$ asl, Aspect: South, Slope: $25^{\circ}$. Vegetation: cypress forest with Quercus ilex, Pistacia terebinthus. Legend: pH $=$ soil reaction; $\mathrm{OM}=$ organic matter; $\mathrm{CEC}=$ cation exchange capacity; $\mathrm{Ca}, \mathrm{K}, \mathrm{Mg}, \mathrm{Na}=$ calcium, potassium, magnesium and sodium exchangeable cations; $\mathrm{BS}=$ base saturation. $\mathrm{C}$ sem = Cupressus sempervirens. 

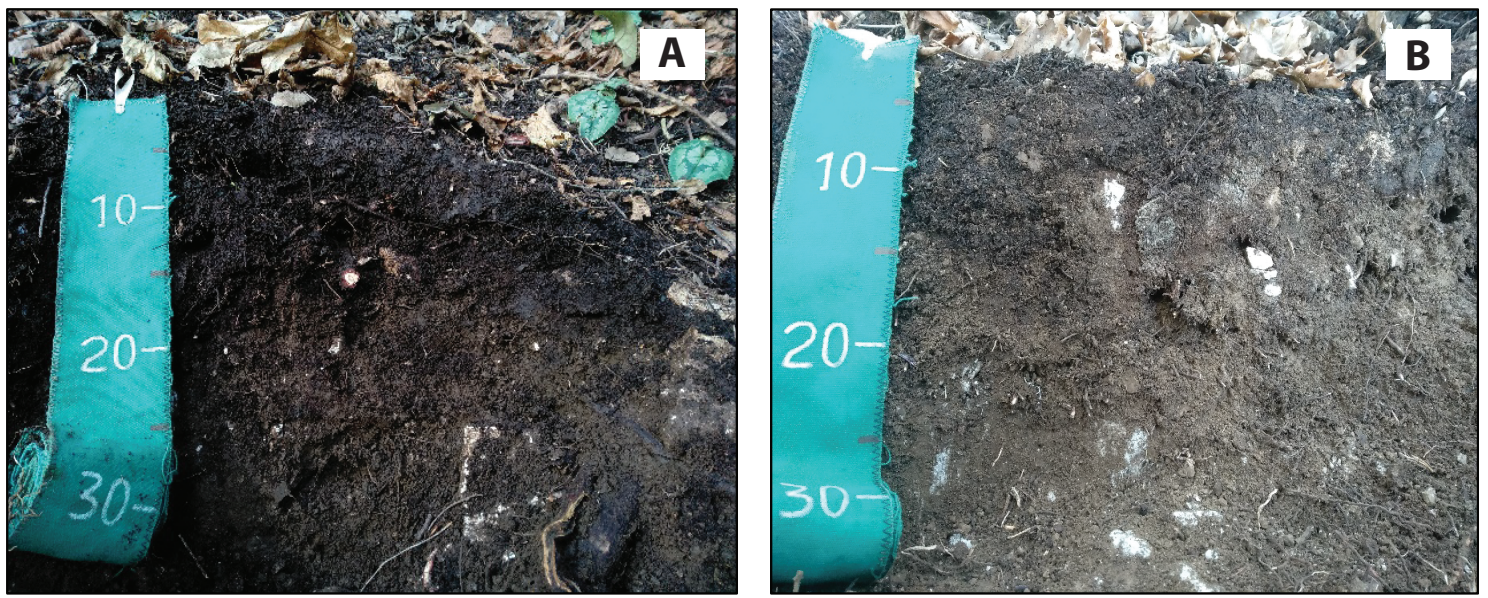

Figure 3. Soil profiles FONT1 (A) and FONT2 (B).

\subsection{Soil Charcoal Data}

All soil samples from the two profiles showed very scarce amounts of charcoals. In detail, for FONT1, 12 charcoals were extracted from the Oe horizon and 79 charcoals from the A1 horizon, while no charcoal was found in the A2. Optical microscopy analyses enabled to identify eight taxa (Table 2) for this profile. The taxonomic differentiation between C. sempervirens and Juniperus sp. is not easy. We used as an anatomical key character the ray height that, in C. sempervirens, is greater than Juniperus sp. (10-15 to 30 cells vs. $2-5$ to 15 cells) $[62,76]$.

In the FONT2 profile, only two charcoals were extracted, and one taxon (Table 3) was identified as C. sempervirens. FONT2 was different from the previous soil, especially for its exposure; indeed, its result was more degraded, more subject to run-off. These characteristics are the consequence of the presence of higher temperature in the soil surface, probably due to a lower tree density and greater solar irradiation of the southern slope.

Therefore, soil charcoal data from the two areas allowed to highlight a forest landscape characterized by various different taxa L1, while a forest cover was only made by the cypress tree for the L2.

\section{4. ${ }^{14} \mathrm{C}$ Dating Analyses}

Examined samples of $C$. sempervirens reported ${ }^{14} C$ contents, which was evidence of significant radiocarbon enrichment concerning $1890 \mathrm{CE}$ (i.e., $\mathrm{F}^{14} \mathrm{C}>1$ ) and chronologically framing our samples in the so-called bomb spike window. This phenomenon is related to a severe anthropogenic effect significantly enriching (i.e., doubling) the natural atmospheric ${ }^{14} \mathrm{C}$ concentrations due to the nuclear bomb testing in the troposphere from $1950 \mathrm{CE}$ to nowadays. Briefly bomb testing produced an aliquot of ${ }^{14} \mathrm{C}$ (namely, Bombcarbon) until the signature of the Test Ban Treaty in 1963, when a sensitive decrease at an annual rate of $1 \%$ to $0.3 \%$ was observed in the atmosphere. This phenomenon allows reducing the uncertainty in calendar age estimation within this period to a few months (soon after 1964) to a few years (nowadays). In detail, measured ${ }^{14} \mathrm{C}$ ages for the individuals falls in the 1991.94-1993.54 AD and 1979.30-1979.94 AD (Figure 4A,B), one-sigma window for FONT1 and FONT2 samples, respectively. Enlargement of such window to two sigma leaves a significant fraction of the probability density to post 1964 intervals. 

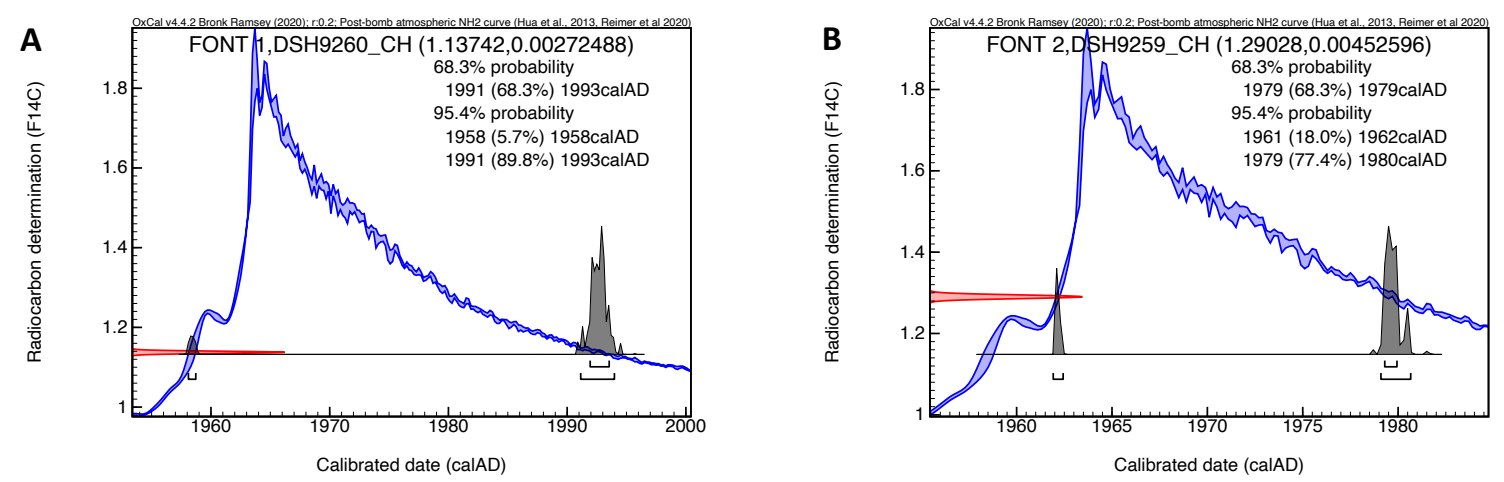

Figure 4. ${ }^{14} \mathrm{C}$ dating of charcoals from FONT1 (A) and FONT2 (B) by AMS (Accelerator Mass Spectrometry).

\section{Discussion and Conclusion}

\subsection{Historical Documentation}

Historical documentation about the Fontegreca forest is scarce and covers approximately the last 500 years. The oldest mention of this forest is dated to 1506 (inheritance tax ante litteram of Norman origin) (Civic Uses of Fontegreca) and implied that it was already a private forest for civic uses (De Rosa 1998) — in particular, grazing (jus pascendi) and wood collection (jus lignandi). This document testifies that, by the early 16th century, this forest already existed, but there is no mention about the presence of cypress trees. The archpriest of the Cathedral of Isernia, in the work "Memoria historica del Sannio" [70], is the first to unearth and describe the forest as a private high stand that managed to produce planks and beams thanks to the technological properties of the wood. Historically, since the pre-Roman times [28], in the Mediterranean area, cypress stands were considered a valid resource for its physical and mechanical wood properties $[77,78]$. This means that, by the middle of the 17 th century, this forest was used for timber production. This fact contradicts the unjustified absence of this forest in the texts of silviculture and forest history [37]. The most recent documents (years 1756, 1776 and 1940; Table 1) only confirmed the existence of this forest, but they did not provide data about both the forest structure and the timber production.

Finally, the diachronic evaluation of the forest area was carried out with the comparison of historical and recent landscape pictures of the study area (years 1940-2019 and 1976-2019, respectively, Figures 5 and 6) enable to identify the expansion of the cypresses with time and to recognize the colonization of the surrounding hornbeam (Carpinus betulus L.) coppice. Since this vegetation dynamic process was already described by Banti [74], much probably on it is ongoing, starting from the middle of the last century. Indeed, Banti reports about a cypress forest of 20 ha, whereas the extent of the cypress forest today is more than tripled, reaching 70 ha [79]. This is proof of the continuous spread of the cypress trees in the surrounding areas and of its ability to naturally renew and colonize areas already occupied by deciduous broadleaf species.

Therefore, by considering that the historical research has allowed ascertaining the presence of the Fontegreca forest since the 16th century, i.e., a mature high forest trees used mainly for grazing and timber production, it is possible to hypothesize that the Fontegreca forest was present even in the centuries before the 16 th.

\subsection{Soil and Charcoal Data}

For the first time, a study was carried out in this forest area using a soil charcoal analysis, which is based on taxonomic identification and the ${ }^{14} \mathrm{C}$ dating of charcoal pieces from soil archives [80]. The presence of the charcoal fragments in the soils is the product of incomplete combustion of the woody vegetation [81]. Botanical identification of charcoal fragments is possible, because the wood structure is conserved during carbonization. The main source leading to the creation of the charcoal assemblage is generally a forest fire caused by lightning or started by humans concerning anthropogenic 
practices [82,83]. Charcoal is composed of inorganic carbon and, therefore, does not decompose in the soil. Indeed, the age of charcoals is strictly related to the age of the soil; this latter usually covers the recent Holocene, even if in some cases can overcome 10,000 yrs [84].
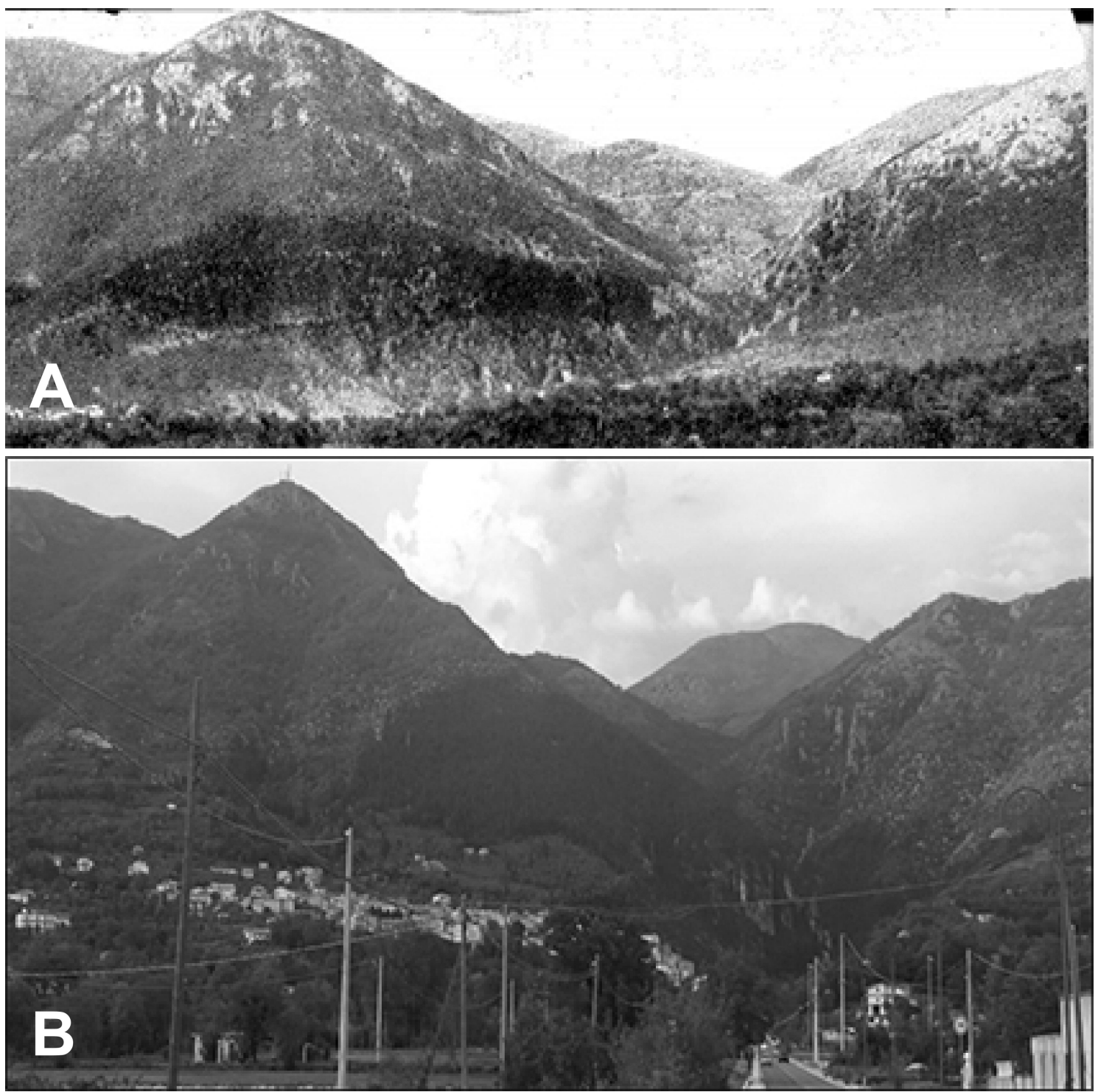

Figure 5. Diachronical comparison between a historical picture of 1940 by Banti (A) and the present of 2019 (B) looking from the same perspective.

In this work, the two ${ }^{14} \mathrm{C}$ dating showed that the charcoal assemblages of both FONT1 and FONT2 (Figure 4A,B), which are very far apart and located on the east and south-facing slopes, respectively (Figure 2), date back to the second half of the 20th century. Based on ${ }^{14} \mathrm{C}$ charcoal ages, it can be assumed that soils are very recent in this area. Differently from other mountain ecosystems of the Campania Region in Southern Italy [85], the soils of Fontegreca do not fulfill the requirements for Andosols classification [86], and no ash or other pyroclastic layers were identified in the soil profiles. Pedological observations did not evidence signs of rubification, a typical weathering and pedogenetic process of the Mediterranean environment acting on limestone rocks and forming "terra rossa". These soils are frequently found on the permeable limestone and dolomite rocks in the Apulia Region (Southern Italy) as the result of several (thousands) years of pedogenesis [87]. In the case of Fontegreca, where the soils (i) are characterized by thin and poorly developed soil horizons, with a subalkaline reaction due to low cation leaching, (ii) developed from hard and poorly of colloids limestone on a moderately high slope 
gradient and (iii) are not Andosols nor terra rossa; we suggest a young age for the soils. An additional phenomenon acting towards a continuous rejuvenation of the Fontegreca soils is the slope erosion. The presence of charcoals older than the 20th century are then not excluded in these soils, so further ${ }^{14} \mathrm{C}$ analyses will surely improve soil dating.

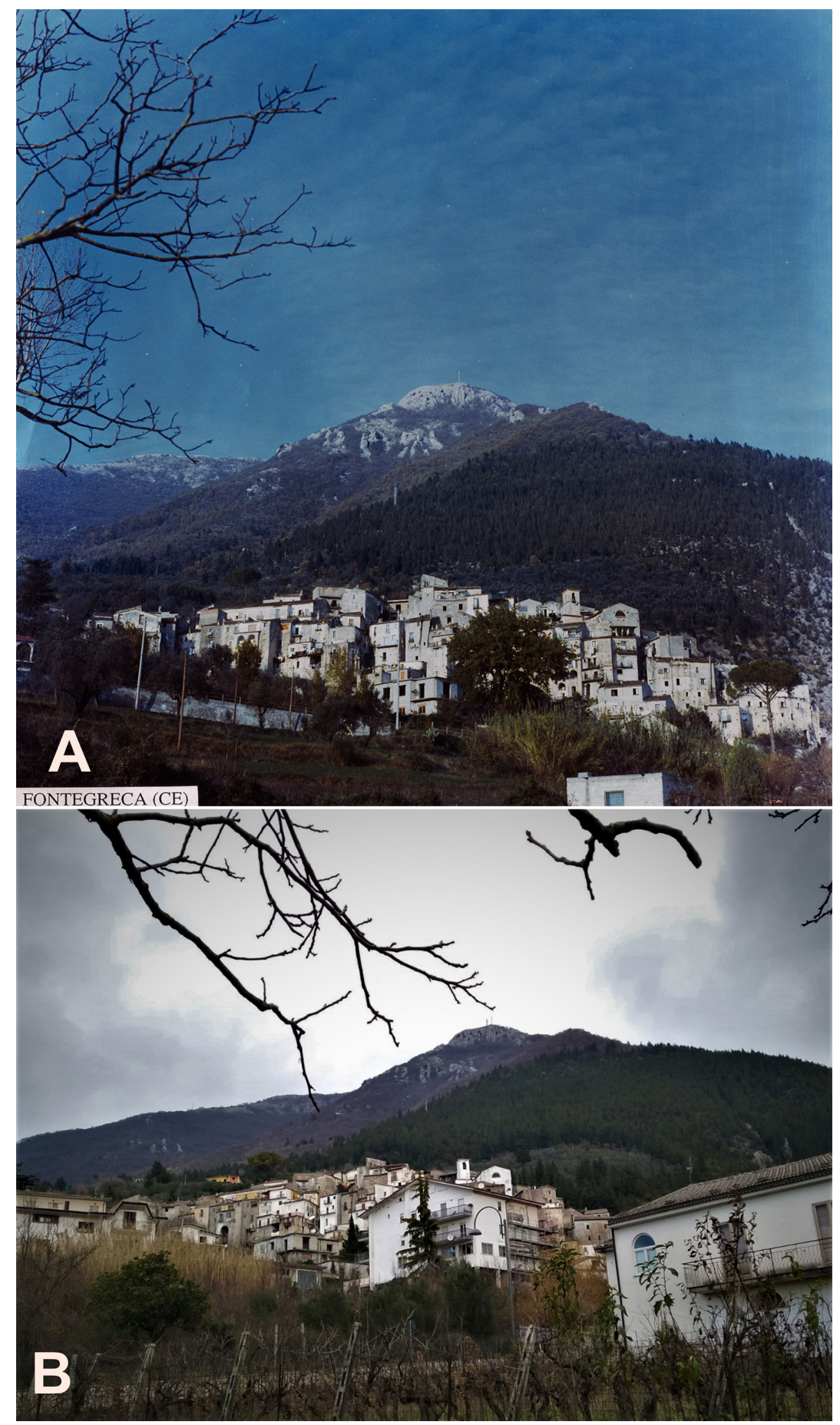

Figure 6. Diachronical comparison between a historical picture of 1976 by Filangieri (A) and the present of 2019 (B).

However, if we take into account the actual radiocarbon age determinations of wood charcoals, they indicate that forest fires fall in a period of intense depopulation of this [72], shortly before the establishment of the Matese Regional Park (2002). In this case, the strong reduction/cessation of the 
human activities gave rise to a transformation from an anthropized forest landscape to a semi-natural system [88], characterized by an increase in terms of the biodiversity and structure. The impact of the forest population density on fire frequency is very well-known; in this case, the land abandonment and, especially, the end of grazing may permit a progressive income of woody species (trees and shrubs) previously grazed by livestock. The presence of Juniperus and Pistacia in FONT1, together with deciduous broadleaved species such as O. carpinifolia, Carpinus and Fagus sylvatica L., could be interpreted as the evidence of the first phase of colonization of the cypress forest. Both Mediterranean Junipers and Pistacia are eliophilous shrubs and/or small trees typical of the maquis vegetation growing on rocky slopes and degraded forests [7]. Interestingly to note that a specific toponomy titled "Colle dei ginepri" was found in a map of the area dated back to 1875, therefore indirectly confirming the presence of a vegetation cover with juniper (presumably, J. oxycedrus) in the surrounding areas of the cypress forest in that period. Indeed, the coexistence of broadleaved tree taxa within heliophiluos shrubs could indicate an open forest, where deciduous trees started to colonize this space. Currently, O. carpinifolia and, to a lesser degree, C. betulus, are the most abundant species found in the coppices surrounding the cypress forest. The presence of $F$. sylvatica is probably related to the local conditions of humidity and temperature that might have favored its local spread. In the charcoal assemblage of FONT 1, the presence of the Pinus-type sylvestris, which includes three species (P. nigra J.F. Arnold, P. mugo Turra and P. sylvestris L.) is relevant. Although the identification of this species by charcoal analysis is generally problematic, due to the absence of specific diagnostic key features in wood anatomy [50], however, their botanical identity can be deduced by their different ecology and distribution [89]. In our study area, the most plausible species was P. nigra (black pine), belonging to a widely distributed species of Mediterranean mountain, with a range extending from North Africa $\left(35^{\circ} \mathrm{N}\right)$ through the Northern Mediterranean, eastwards to the Black sea and, finally, in the western Mediterranean (Corsica and Sicily, both as P. nigra subsp. laricio). Interestingly, black pine forests are today limited to a few relic carbonatic rocky reliefs where they form open woodlands on the steep slopes of the Italian peninsula [89]. Finally, C. sempervirens charcoals are present, to a limited extent, in FONT1 and 2. An explanation of the scarcity of the finds could be that $C$. sempervirens var. horizontalis is characterized by peculiar and lower flammability traits compared to other Mediterranean species [90,91]. Moreover, the very scarce amount of charcoals in FONT2 is probably due to this specific behavior during wildfires, as well as to the more open forest structure defining (and defined also in the past) this south-facing slope.

In conclusion, historical documents confirmed (1) the presence of the cypress forest of Fontegreca since the beginning of the 16th century (2) and its management, mainly for grazing and timber production. Over the centuries, the continuous civic use (mainly grazing) has slowed down, if not halted, the colonization of the cypress forest, which was still preserved in good condition until today, probably thanks to the activities carried out by private owners. Although paradoxically, the flight from the land occurred in the past years together with the increase of the constraints in the use of agroforestry resources due to the park laws can cause an increase in biodiversity that can put the cypress forest at risk. Nevertheless, from the second half of the 20th century, in the study area, the cypress forest has expanded significantly, proving the capability of this species to regenerate naturally and even colonize other portions of the surrounding forests or abandoned coppice lands. Finally, soil charcoal data together with the extreme accuracy of the ${ }^{14} \mathrm{C}$ dating and soils analysis allowed us to investigate the forest species composition and to restrict this information to a specific date, which is unfortunately quite recent due to the extreme youngness of the investigated soils. Looking ahead, as the origin of the Fontegreca forest remains still unknown, future research will be dedicated to solving this biogeographic enigma.

Author Contributions: Conceptualization, A.D., S.V. and G.D.P.; methodology, A.D., S.V. and F.M.; formal analysis, A.D., S.V. and F.M.; investigation, A.D., S.V. and G.D.P.; resources, S.V., G.D.P. and F.M.; data curation, A.D., S.V. and F.M.; writing-original draft preparation, A.D., S.V., G.D.P. and M.T.; writing-review and editing, A.D., S.V., G.D.P., F.M. and M.T.; visualization, A.D. and S.V. and supervision, G.D.P. All authors have read and agreed to the published version of the manuscript. 
Funding: This research received no external funding.

Acknowledgments: The authors wish to acknowledge Maria Merola for her work of collection of the historical documents on C. sempervirens and laboratory analysis on soils and charcoals identification.

Conflicts of Interest: The authors declare no conflict of interest.

\section{References}

1. Zohary, D.; Hopf, M. Domestication of Plants in the Old World: The Origin and Spread of Cultivated Plants in West Asia, Europe, and the Nile Valley; Oxford University Press: Oxford, UK, 2000; 316p.

2. Sękiewicz, K.; Dering, M.; Romo, A.; Dagher-Kharrat, M.B.; Boratyńska, K.; Ok, T.; Boratyński, A. Phylogenetic and biogeographic insights into long-lived Mediterranean Cupressus taxa with a schizo-endemic distribution and Tertiary origin. Bot. J. Linn. Soc. 2018, 20, 1-23. [CrossRef]

3. Birks, H.J.B.; Tinner, W. Past forests of Europe. In European Atlas of Forest Tree Species, 1st ed.; San-Miguel, J., De Rigo, D., Caudullo, O., Durrant, T.H., Eds.; Publication Office of the European Union: Luxembourg, 2016; pp. 36-39.

4. Zohary, G.; Hopf, M.; Weiss, E. Domestication of Plants in the Old World: The Origin and Spread of Domesticated Plants in Southwest Asia, Europe, and the Mediterranean Basin; Oxford University Press: Oxford, UK, 2012; 264p.

5. Romàn-Jordàn, E.; Esteban, L.G.; De Palacios, P.; Fernàndez, F.G. Wood Anatomy of Cupressus and its relation to geographical distribution. IAWA J. 2016, 37, 48-68.

6. Caudullo, G.; de Rigo, D. Cupressus sempervirens in Europe: Distribution, habitat, usage and threats. In European Atlas of Forest Tree Species; San-Miguel-Ayanz, J., de Rigo, D., Caudullo, G., Durrant, T.H., Mauri, A., Eds.; Publication Office of the European Union: Luxembourg, 2016.

7. Quézel, P.; Médail, F. Ecologie et Biogéographie des Foréts du Basin Méditerranéen; Elsevier: Amsterdam, The Netherlands, 2003; 574p.

8. Sękiewicz, K.; Boratyńska, K.; Dagher-Kharrat, M.B.; Ok, T.; Boratyński, A. Taxonomic differentiation of Cupressus sempervirens and C. atlantica based on morphometric evidence. Syst. Biodivers. 2016, 14, 494-508. [CrossRef]

9. Little, D.P. Evolution and circumscription of the true cypresses (Cupressaceae: Cupressus). Syst. Bot. 2006, 31, 461-480. [CrossRef]

10. Bagnoli, F.; Della Rocca, G.; Spanu, I.; Fineschi, S.; Vendramin, G.G. The origin of the Afro-Mediterranean cypresses: Evidence from genetic analysis. Perspect. Plant Ecol. Evol. Syst. 2020, 46, 125564. [CrossRef]

11. Farjon, D. An Atlas of the World's Conifers: An Analysis of their Distribution, Biogeography, Diversity and Conservation Status; Brill: Leiden, The Netherlands, 2013; 512p.

12. Farjon, A. A Handbook of the Word's Conifer; Brill: Leiden, The Netherlands, 2010; 1112p.

13. Eckenwalder, E. Conifers of the World: The Complete Reference; Timber Press: Portland, OR, USA, 2009.

14. Panetsos, C.P. Inherited Differences Between Populations and Individuals of Cupressus sempervirens L.; Ministry of Agriculture, Forest Research Institute: Athens, Greece, 1967; 19p.

15. Johnson, L.C. Cupressus L.-Cypress. In Seeds of Woody Plants in the US; Schopmeyer, C.S., Ed.; Forest Service, US Department of Agriculture: Washington, DC, USA, 1974; pp. 363-369.

16. Del Favero, R.; Bolzon, P. I Boschi Delle Regioni Dell'italia Centrale: Tipologia, Funzionamento, Selvicoltura; Cleup: Padova, Italy, 2010; 426p.

17. Vermigli, M.C. Genetic Variability in Italian Populations of Cupressus sempervirens L., Assessed by SSR and Rapid Markers. Ph.D. Thesis, University of Verona, Verona, Italy, 2005.

18. Lev-Yadun, S.; Weinstein-Evron, M. Late Epipalaeolithic wood remains from el-Wad Cave, Mount Carmel, Israel. N. Phytol. 1994, 127, 391-396. [CrossRef]

19. Carroll, F.A.; Hunt, C.O.; Schembri, P.J.; Bonanno, A. Holocene primate change, vegetation history and human impact in the Central Mediterranean: Evidence from the Maltese islands. Quat. Sci. Rev. 2012, 52, 24-40. [CrossRef]

20. Follieri, M. Conifer extinction in quaternary Italian records. Quat. Int. 2010, 225, 37-43. [CrossRef]

21. Pini, R.; Bertini, A.; Martinetto, E.; Vassio, E. The pleistocene flora of Northern Italy. In Palaeobotany of Italy; Kustatscher, E., Roghi, G., Bertini, A., Miola, A., Eds.; Naturmuseum Südtirol: Bolzano, Italy, 2014; pp. 290-307. 
22. Combourieu-Nebout, N.; Bertini, A.; Ermolli, E.R.; Peyron, O.; Klotz, S.; Montade, V.; Fauquette, S.; Allen, J.; Fusco, F.; Goring, S.; et al. Primate changes in the central Mediterranen and Italian vegetation dynamics since the Pliocene. Rev. Palaeobot. Palynol. 2015, 218, 127-147. [CrossRef]

23. Mijarra, J.M.P.; Barròn, E.; Manzaneque, F.G.; Morla, C. Floristic changes in the Iberian Peninsula and Balearic Islands (south-west Europe) during the Cenozoic. J. Biogeogr. 2009, 36, 2025-2043. [CrossRef]

24. Magri, D. Quaternary history of Cedrus in southern Europe. Ann. Bot. 2012, 2, 57-66.

25. Bagnoli, F.; Vendramin, G.G.; Buonamici, A.; Doulis, A.G.; Gonzàles-Martìnez, S.C.; La Porta, N.; Magri, D.; Raddi, P.; Sebastiani, F.; Fineschi, S.; et al. Is Cupressus sempervirens native in Italy? An answer from genetic and palaeobotanical data. Mol. Ecol. 2009, 18, 2276-2286. [CrossRef]

26. Maerki, D.; Frankis, M.P. A new Cupressus fossil species in Italy. Bull. Cupress. Conserv. Proj. 2018, 7, 81.

27. Zacharis, A. The Forest of Crete from the Ancient Times Up to Day. In Prize of Athens Academy; Ministry of Agriculture, Service Forest Practice and Education: Athens, Greece, 1977; 146p.

28. D'Auria, A.; Teobaldelli, M.; Di Pasquale, G. The late Holocene history of cypress (Cupressus sempervirens L.) in the Italian peninsula: New perspectives from archaeobotanical data. Holocene 2020, 30, 210-217. [CrossRef]

29. Moser, D.; Nelle, O.; Di Pasquale, G. Timber economy in the roman age: Charcoal data from the key site of Herculaneum (Naples, Italy). Archaeol. Anthropol. Sci. 2018, 10, 905-921. [CrossRef]

30. Vecchio, P.I. Naturalis Historia; Einaudi: Torino, Italy, 1997; 645p.

31. Berti, R.N. La Struttura Anatomica del Legno ed il Riconoscimento dei Legnami Italiani di Più Corrente Impiego; CNR-Invalsa: Florence, Italy, 2006.

32. Colaianni, G.; Scelza, F.; Fiorentino, G.; Pontrandolfo, A.; Santoriello, A.; Orrico, D. Well lining in ancient hydrological system of Fratte settlement (Salerno, Italy): Cypress wood use in the Archaic period (6th-5th century BC). SAGVNTVM Extra 2011, 11, 195-196.

33. Coccolini, O.; Follieri, M. I Iegni dei pozzi del tempio A nel santuario etrusco di Pyrgi. Studi Etruschi 1980, $48,277-291$.

34. Lippi, M.M.; Bellini, C.; Secci, M.M. Palaeovegetational reconstruction based on pollen and seeds/fruits from a Bronze Age archaeological site in Tuscany (Italy). Plant Biosyst. 2010, 144, 902-908. [CrossRef]

35. Bernetti, G. Selvicoltura Speciale; UTET: Torino, Italy, 1995; 415p.

36. Pignatti, S. Flora D'Italia, 1st ed.; Edagricole: Bologna, Italy, 1982; Volume 1, pp. 82-83.

37. Di Bérenger, A. Studii di Archeologia Forestale; Accademia Italiana di Scienze Forestali e della Direzione Generale dell'Economia Montana e delle Foreste: Florence, Italia, 1859; 86p.

38. De Rosa, M. Il bosco degli Zappini (Caserta). Un caso di cipresseta (Cupressus sempervirens L.) subnaturale. L'Italia Forestale e Montana 1998, 53, 210-219.

39. Mostardini, S.; Merlini, S. Appennino centro meridionale: Sezioni geologiche e proposta di modello strutturale. Mem. Soc. Geol. Ital. 1986, 35, 177-202.

40. Di Gennaro, A.; Aronne, G.; De Mascellis, R.; Vingiani, S.; Sarnataro, M.; Abalsamo, P.; Cona, F.; Vitelli, L.; Arpaia, G. I Sistemi di Terre della Campania: Monografia e Carta 1: 250,000, con Legenda; SELCA: Florence, Italy, 2002; 63p.

41. Shoji, S.; Nanzyo, M.; Dahlgren, R.A. Volcanic Ash Soils: Genesis, Properties and Utilization; Elsevier: Amsterdam, The Netherlands, 1993.

42. Maeda, T.; Takenaka, H.; Warkentin, B.P. Physical properties of allophane soils. Adv. Agron. 1977, $29,229-264$.

43. Vingiani, S.; Buonanno, M.; Coraggio, S.; D'Antonio, A.; De Mascellis, R.; Di Gennaro, A.; Iamarino, M.; Langella, G.; Manna, P.; Moretti, P.; et al. Soils of the Aversa plain (southern Italy). J. Maps 2018, 14, 312-320. [CrossRef]

44. Vingiani, S.; Minieri, L.; Livadie, C.A.; Di Vito, M.A.; Terribile, F. Pedological investigation of an early Bronze Age site in southern Italy. Geoarchaeology 2018, 33, 193-217. [CrossRef]

45. Mileti, F.A.; Vingiani, S.; Manna, P.; Langella, G.; Terribile, F. An integrated approach to studying the genesis of andic soils in Italian non-volcanic mountain ecosystems. Catena 2017, 159, 35-50. [CrossRef]

46. Terribile, F.; Iamarino, M.; Langella, G.; Manna, P.; Mileti, F.A.; Vingiani, S.; Basile, A. The hidden ecological resource of andic soils in mountain ecosystems: Evidence from Italy. Solid Earth 2018, 9, 63-74. [CrossRef]

47. Scognamiglio, S.; Basile, A.; Calcaterra, D.; Iamarino, M.; Langella, G.; Moretti, P.; Vingiani, S.; Terribile, F. Andic soils and flow-like landslides: Cause-effect evidence from Italy. Land Degrad. Dev. 2019, 30, 128-140. [CrossRef] 
48. Vingiani, S.; Mele, G.; De Mascellis, R.; Terribile, F.; Basile, A. Volcanic soils and landslides: A case study of the island of Ischia (southern Italy) and its relationship with other Campania events. Solid Earth 2015, 6, 783-797. [CrossRef]

49. Kabata-Pendias, A. Trace Elements in Soils and Plants; CRC Press: Boca Raton, FL, USA, 2001.

50. Latrille, C.; Denaix, L.; Lamy, I. Interaction of copper and zinc with allophane and organic matter in the B horizon of an Andosol. Eur. J. Soil Sci. 2003, 54, 357-364. [CrossRef]

51. Centro Funzionale Multirischi Protezione Civile Regione Campania, 2008-2020. Available online: http: //centrofunzionale.regione.campania.it/\#/pages/sensori/archivio-pluviometrici (accessed on 29 November 2020).

52. Fiorucci, R. Il fitonimo zappino, etimologia e diffusione. Il caso dell'eteronimo di Fontegreca (CE). For. J. Silvic. For. Ecol. 2018, 15, 3-17.

53. Raddi, P.; Danti, R.; Zumolo, A.; Montoro, A.; Fusco, M.; Apuzzo, S. L'arboreto Clonale da Seme: Il futuro della Cipresseta di Fontegreca; Edistampa SUD, S.R.L.: Rome, Italy, 2014; 64p.

54. Jahn, R.; Blume, H.P.; Asio, V.B.; Spaargaren, O.; Schad, P. Guidelines for Soil Description; Food and Agriculture organization of the United Nations: Rome, Italy, 2006; 109p.

55. Walkley, A.; Black, I.A. An examination of the Degtjareff method for determining soil organic matter, and a proposed modification of the chromic acid titration method. Soil Sci. 1934, 37, 29-38. [CrossRef]

56. Mehlich, A. Use of triethanolamine acetate-barium hydroxide buffer for the determination of some base exchange properties and lime requirement of soil. Soil Sci. Soc. Am. Proc. 1938, 29, 374-378. [CrossRef]

57. Carcaillet, C.; Thinon, M. Pedoanthracological contribution to the study of the evolution of the upper treeline in the Maurienne valley (North French Alps): Methodology and preliminary data. Rev. Palaeobot. Palynol. 1996, 91, 399-416. [CrossRef]

58. Talon, B. Reconstruction of Holocene high-altitude vegetation cover in the French southern Alps: Evidence from soil charcoal. Holocene 2010, 20, 35-44. [CrossRef]

59. Greguss, P. Identification of Living Gymosperms on the Basis of Xylotomy; Akadémiai Kiadò: Budapest, Hungary, 1955.

60. Greguss, P. Holzanatomie der Europäischen Laubhölzer und Sträucher; Akadémiai Kiadò: Budapest, Hungary, 1959.

61. Vernet, J.L. Guide D'identification des Charbons de Bois Préhistoriques et Récents; CNRS: Paris, France, 2001.

62. Schweingruber, P.H. Anatomy of European Woods; Verlag Paul Haupt: Stuttgart, Germany, 1990; p. 800.

63. Passariello, I.; Marzaioli, F.; Lubritto, C.; Rubino, M.; D’Onofrio, A.; De Cesare, N.; Borriello, G.; Casa, G.; Palmieri, A.; Rogalla, D.; et al. Radiocarbon sample preparation at the CIRCE AMS laboratory in Caserta, Italy. Radiocarbon 2007, 49, 225-232. [CrossRef]

64. Marzaioli, F.; Borriello, G.; Passariello, I.; Lubritto, C.; De Cesare, N.; D'Onofrio, A.; Terrasi, F. Zinc reduction as an alternative method for AMS radiocarbon dating: Process optimization at CIRCE. Radiocarbon 2008, 50, 139-149. [CrossRef]

65. Terrasi, F.; Rogalla, D.; De Cesare, N.; D’Onofrio, A.; Lubritto, C.; Marzaioli, F.; Passariello, I.; Rubino, M.; Sabbarese, C.; Casa, G.; et al. A new AMS facility in Caserta/Italy. Nucl. Instrum. Methods Phys. Res. Sect. B Beam Interact. Mater. At. 2007, 259, 14-17. [CrossRef]

66. Terrasi, F.; De Cesare, N.; D’Onofrio, A.; Lubritto, C.; Marzaioli, F.; Passariello, I.; Rogalla, D.; Sabbarese, C.; Borriello, G.; Casa, G.; et al. High precision 14C AMS at CIRCE. Nucl. Instrum. Methods Phys. Res. Sect. B Beam Interact. Mater. At. 2008, 266, 2221-2224. [CrossRef]

67. Stuiver, M.; Polach, H. Discussion reporting of 14C data. Radiocarbon 1977, 19, 355-363. [CrossRef]

68. Ramsey, C.B. Methods for summarizing radiocarbon datasets. Radiocarbon 2017, 59, 1809-1833. [CrossRef]

69. Hua, Q.; Barbetti, M.; Rakowski, A. Atmospheric radiocarbon for the period 1950-2010. Radiocarbon 2013, 55, 2059-2072. [CrossRef]

70. Ciarlanti, G.V. Memorie Historiche del Sannio; Libreria Oreste Gozzini: Florence, Italy, 1633; Volume 1, 530p.

71. Sacro Regio Consiglio. Ordinamento Zeni; Archivio di Stato di Napoli: Naples, Italy, 1756; Volume 2, 147p.

72. Trutta, G. Dissertazioni Istoriche delle Antichità Alifane; Stamperia Simoniana: Naples, Italy, 1776; 420p.

73. Buontempo, M. Comune di Fontegreca: Sistemazione Demaniale; Dattiloscritto Inedito: Milan, Italy, 1933; 41p.

74. Banti, G. Una cipresseta sugli ultimi contrafforti del Matese. Rivista Forestale Italiana 1940, 2, 364-367.

75. Aucelli, P.P.; Cesarano, M.; Di Paola, G.; Filocamo, F.; Rossokopf, C.M. Geomorphological map of the central sector of the Matese Mountains (Southern Italy): An example of complex landscape evolution in a Mediterranean mountain environment. J. Maps 2013, 9, 604-616. [CrossRef]

76. DELTA-DEscription Language for Taxonomy. Available online: www.delta-intkey.com (accessed on 29 November 2020). 
77. Giordano, G. Tecnologia del Legno: La Materia Prima; Unione Topografico-Editrice Torinese: Torino, Italy, 1981; Volume 1, 768p.

78. Berti, S.; Macchioni, S. Caratteristiche tecnologiche e commerciali del legno di cipresso. In Il Cipresso dalla Leggenda al Futuro; Panconesi, A., Ed.; Consiglio Nazionale delle Ricerche, Istituto per la Protezione delle Piante-CNR: Florence, Italy, 2007; pp. 193-204.

79. De Benedictis, R. Piano di Assestamento Forestale: 2018-2027, San Gregorio Matese (CE), Ordine Dottori Agronomi e Forestali, Prov. Caserta. Available online: http://www.sito.regione.campania.it/agricoltura/ foreste/PGF_San_Gregorio_Matese.pdf (accessed on 29 November 2020).

80. Pescini, V. Which origin for charcoal in soils? Case-studies of environmental resources archaeology (ERA) from the Ligurian Apennines, 7th to the 20th century. Front. Environ. Sci. 2019, 7, 77. [CrossRef]

81. Forbes, M.S.; Raison, R.J.; Skjemstad, J.O. Formation, transformation and transport of black carbon (charcoal) in terrestrial and aquatic ecosystems. Sci. Total Environ. 2006, 370, 190-196. [CrossRef]

82. Carcaillet, C.; Barakat, H.; Panaiotis, C.; Loisel, R. Fire and late Holocene expansion of Quercus ilex and Pinus pinaster on Corsica. J. Veg. Sci. 1997, 8, 85-94. [CrossRef]

83. Pyne, S.; Goldammer, J.G. The culture of fire: An introduction to anthropogenic fire history. In Sediment Records of Biomass Burning and Global Change; Clark, J.S., Cachier, H., Goldammer, J.G., Stocks, B., Eds.; Springer: Berlin/Heidelberg, Germany, 1997; pp. 71-114.

84. Di Pasquale, G.; Marziano, M.; Impagliazzo, S.; Lubritto, C.; De Natale, A.; Bader, M.Y. The Holocene treeline in the northern Andes (Ecuador): First evidence from soil charcoal. Palaeogeogr. Palaeoclimatol. Palaeoecol. 2008, 259, 17-34. [CrossRef]

85. Vingiani, S.; Scarciglia, F.; Mileti, F.A.; Donato, P.; Terribile, F. Occurrence and origin of soils with andic properties in Calabria (southern Italy). Geoderma 2014, 232, 500-516. [CrossRef]

86. IUSS Working Group WRB. World Reference Base for Soil Resources 2014, Update 2015 International Soil Classification System for Naming Soils and Creating Legends for Soil Maps; Technical Report No. 106; Food and Agriculture Organization: Rome, Italy, 2015.

87. Vingiani, S.; Di Iorio, E.; Colombo, C.; Terribile, F. Integrated study of red Mediterranean soils from southern Italy. Catena 2018, 159, 35-50. [CrossRef]

88. Mazzoleni, S.; Di Pasquale, G.; Mulligan, M.; Di Martino, P.; Rego, F. Recent Dynamics of the Mediterranean Vegetation and Landscape; John Wiley \& Sons, Ltd.: Hoboken, NJ, USA, 2004; p. 301.

89. Di Pasquale, G.; Saracino, A.; Bosso, L.; Russo, D.; Moroni, A.; Bonanomi, G.; Allevato, E. Coastal pine-oak glacial refugia in the Mediterranean basin: A biogeographic approach based on charcoal analysis and spatial modelling. Forests 2020, 11, 673. [CrossRef]

90. Rocca, G.D.; Hernando, C.; Madrigal, J.; Danti, R.; Moya, J.; Guijarro, M.; Pecchioli, A.; Moya, B. Possible land management uses of common cypress to reduce wildfire initiation risk: A laboratory study. J. Environ. Manag. 2015, 159, 68-77. [CrossRef]

91. Rocca, G.D.; Danti, R.; Raddi, P.; Moya, B.; Moya, J. Mise en oeuvre du systéme cyprè pour des barriéres vertes coupe-feu. Foret Méditerranéenne 2014, 35, 269-274.

Publisher's Note: MDPI stays neutral with regard to jurisdictional claims in published maps and institutional affiliations.

(C) 2020 by the authors. Licensee MDPI, Basel, Switzerland. This article is an open access article distributed under the terms and conditions of the Creative Commons Attribution (CC BY) license (http://creativecommons.org/licenses/by/4.0/). 